\title{
Abortion law reform in Victoria: lessons for the UK
}

\section{Sally Sheldon}

Professor of Law, Kent Law School, Eliot College, Kent University, Canterbury, UK

\section{Correspondence to}

Professor Sally Sheldon, Kent Law School, Eliot College, Kent University, Canterbury CT2 7NS, UK; S.Sheldon@kent.ac.uk

Received 13 November 2016 Accepted 20 November 2016

\section{CLLinked}

http://dx.doi.org/10.1136/ jfprhc-2016-101541

\section{CrossMark}

To cite: Sheldon S. J Fam Plann Reprod Health Care 2017;43:25.
The decriminalisation of abortion in Victoria was greeted by one commentator as changing both nothing and everything: "[n]othing, because the number, rate and incidence of abortion will not change. And everything, because for the first time women will be recognised as the authors of our own lives. With that comes our full citizenship". ${ }^{1}$

Victoria does not collect data regarding the incidence of abortion and, until now, the only evidence against which to assess these predictions has been anecdotal. Keogh et al.'s ${ }^{2}$ study in this issue provides the first robust confirmation that the incidence of legal abortions has not risen since decriminalisation. Neither has the removal of criminal sanction led to more late terminations. These are important findings not just for Victoria but also for any other jurisdiction considering liberalising reform. The British tabloid newspaper, The Daily Mail, recently described as "abhorrent" a campaign to achieve similar changes to the law in Britain. It cited fears that such changes would "lead to healthy foetuses being aborted late in pregnancy for the convenience of the mother or because they were the 'wrong' sex". 3 The Victorian experience suggests that such concerns are ill-founded.

However, this study ${ }^{2}$ also demonstrates that the removal of specific criminal prohibitions against abortion should not be seen as a panacea. Indeed, albeit for reasons apparently unconnected with the legal reform, it found that public service provision and access to later abortion services appear actually to have decreased in Victoria since 2008. The fact that abortion is legal was welcomed by study participants as removing the threat of criminal prosecution but that alone will not necessarily result in the willingness of doctors to provide terminations. While legalisation can offer important legitimation of abortion services, it will not instantly remove the stigma that attaches to those who seek access to, or work within, them. Moreover, in Victoria, further legislation has been deemed necessary to provide 'buffer zones' around clinics, which ensure that protesters' free speech rights are not permitted to result in the obstruction or harassment of women seeking access to lawful services.

Whatever the shortcomings of legal reform, Keogh et al.'s ${ }^{2}$ study nonetheless suggests that the sweeping away of criminal law prohibitions against abortion in Victoria has been a crucial first step towards improving services. Respondents accepted that reform had been important in repositioning abortion as a health issue, rather than a matter for criminal law, and in transferring formal legal decision-making powers from doctors to women. However, they were equally clear that further work remains to be done in ensuring equitable access to excellent, modern abortion services. Those considering legal reform in other jurisdictions, such as the UK, should take note.

Competing interests None declared.

Provenance and peer review Commissioned; internally peer reviewed.

\section{REFERENCES}

1 Wainer J. Celebrate sisters, the battle is won. New Matilda, 25 November 2008. https:/ newmatilda.com/2008/11/25/celebrate-sistersbattle-won [accessed 12 November 2016].

2 Keogh LA, Newton D, Bayly C, et al. Intended and unintended consequences of abortion law reform: perspectives of abortion experts in Victoria, Australia. J Fam Plann Reprod Health Care 2017;43:18-24.

3 Greenhill S, Spencer B. Midwives revolt over abortion: fury as their feminist union chief backs bid to axe ANY time limit on terminations. The Daily Mail, 16 May 2016. http://www.dailymail. co.uk/news/article-3591935/Midwives-revoltabortion-feminist-union-chief-backs-bid-axetime-limit-terminations.html\#ixzz4PtisI9jZ [accessed 12 November 2016]. 